\title{
Use of Microsite Sampling to Reduce Inventory Sample Size
}

\author{
L.L. LARSON AND P.A. LARSON
}

\begin{abstract}
The objective of this study was to determine if a stratification of microsites within range communities could be used to effectively reduce sampling variation and hence sample size. Two grassland communities were stratified by microrelief patterns. Random sampling designs were applied to each community as well as microsites within the community. Stratification of the community, based on local drainage patterns, reduced standard errors significantly. The pooled microsite data sets were not significantly different from simple random sample data sets for the communities. Sample size reductions of 50 and $60 \%$ were observed using the microsite sampling technique.
\end{abstract}

\section{Key Words: inventory, sample size}

Vegetation inventories provide information that is used to formulate land management decisions (McQuisten and Gebhardt 1983). The trend in range management and mined land reclamation has been to utilize objective sampling designs that yield valid statistical inferences about the area being studied. Much of this trend is the direct result of our increased reliance upon analytical results for regulation, enforcement, and litigation (McQuisten and Gebhardt 1983). Unfortunately, this trend has also raised inventory costs.

A number of sampling procedures and improvements have been described in the literature during the past 5 years (Shute and West 1982, Ahmed et al. 1983, Butler and McDonald 1983, Strauss and Neal 1983, Taha et al. 1983, and Caranda and Jameson 1986). However, it is important to be aware that many reductions in inventory costs depend on the ability of the sampler to identify sources of sampling variation and to develop study designs that will minimize the number of samples needed to obtain valid statistical inferences. Partitioning of internal sources of community variation should be a primary objective when sample size is a limiting factor. The objective of this study was to determine if a stratification of microsites within range communities could be used to effectively reduce sampling variation and hence inventory sample size.

\section{Methods}

Bluegrass (Poa sandbergii/ Stipa comata) and needlegrass (Stipa comata / Stipa columbiana) communities near Williams Lake and Merritt, British Columbia, were selected for this study. Each community was mapped to form microsites based on drainage patterns within the community. The partitioning process has the potential of identifying 4 possible patterns of microsite relief within a given community: (1) The nose-the driest areas of the community usually having off-site drainage, (2) Side slopes-areas with straight contours and gradual off-site drainage, (3) Foot slopes-the gentle lower parts of the side slope, and (4) Hollows - areas of drainage accumulation (Cook and Doornkamp 1974).

Each community was sampled using Daubenmire quadrats (20 $\times 50 \mathrm{~cm}$ ). The placement of the individual quadrats was determined by using a random sequence of compass bearings and distances within the communities. Each observation was recorded by sample number and microsite position. Foliar cover and herbage yield data were collected by species. Green herbage weights were adjusted using correction factors obtained from oven-dry samples $\left(65^{\circ} \mathrm{C}\right)$. Sample adequacy for vegetation cover and wet herbage

Authors are assistant professor, Department of Rangeland Resources, Oregon State University, and ecological consultant, LaGrande Oregon.

Manuscript accepted 9 March 1987. yield were monitored in the field using Stein's two-stage sampling procedure (Steel and Torrie 1980). Sample size requirements for the cover estimates were larger than those observed for wet herbage yield. Consequently, the sample size requirements for the cover estimates were used as the minimal sample size requirements for subsequent comparisons.

Two sets of data were provided by this procedure: (1) A simple random sample for the entire community, and (2) A stratified data set based on drainage patterns within the community. Community estimates from the microsite data were obtained by aggregating the stratified data sets. Weighted mean and standard error calculations for stratified samples (Snedeor and Cochran 1978) were used to obtain these estimates. A planimeter was used to obtain area estimates (weighing factor) for the microsites.

\section{Results and Discussion}

The stratification process recognized 3 microsites in the bluegrass community (nose, slope, and hollow) and 2 sites in the needlegrass community (nose and slope). The number of microsites in each community is a function of the drainage pattern of the land area and the community boundary. The results of an analysis of variance of these data sets are provided in Table 1 . In both communities microsite differences were shown to be significant sources of community variation. Mean differences between the strata ranged from 19-60\% cover in the bluegrass community and $17-44 \%$ cover in the needlegrass community. Similar differences were observed in wet and dry herbage yield (bluegrass: 11.8-56 $\mathrm{g} / .1 \mathrm{~m}^{2}, 5.4-24.5 \mathrm{~g} / .1 \mathrm{~m}^{2}$; needlegrass: $13.8-20.8 \mathrm{~g} / . \mathrm{m}^{2}, 5.7-11.7$ $\mathrm{g} / .1 \mathrm{~m}^{2}$ ). From a sampling perspective, stratification reduced the standard errors associated with the population estimates by $46 \%$ for cover, $43 \%$ for dry herbage yield, and $44 \%$ for wet herbage yield in the bluegrass community. Results were similar in needlegrass community: standard errors were reduced $42 \%$ for cover, $32 \%$ for dry herbage yield, and $23 \%$ for wet herbage yield. The standard error reductions indicate that the accumulative influence of microsite drainage patterns contributes a significant proportion of the variability found in the vegetation cover and herbage yield estimates for the community.

Microsite sampling reduced the overall sample size requirements for the $\mathbf{2}$ communities by $50 \%$ for the bluegrass community and $60 \%$ for the needlegrass community (Table 2). The sample size numbers reported in Table 2 represent the largest sample size required to meet the stated confidence level for all 3 community attributes. The number is a composite of the random samples collected from the respective microsites. The weighted mean estimates for the bluegrass cover, dry herbage yield, wet herbage yield and the needlegrass cover and wet herbage yield estimates fall within 1 standard error of the simple random sample estimates for communities. The weighted estimate for dry herbage yield in the needlgrass community exceeded 1 standard error but is within 1.7 standard errors of the simple random estimate of the mean. Consequently, the confidence limits for both communities indicate that there is no significant difference between population estimates obtained using simple random sampling or microsite sampling.

\section{Conclusion}

Rangeland inventories are normally conducted on limited budgets, which underscores the need for maximizing the information obtained through the inventory process. In addition inventory funding determines to a large extent inventory sample size (Steel 
Table 1. Analysis of variance of strata data sets from the bluegrass and needlegrass communities.

\begin{tabular}{|c|c|c|c|c|c|c|c|c|c|}
\hline \multirow[b]{2}{*}{ Attribute } & \multirow[b]{2}{*}{ Source } & \multicolumn{4}{|c|}{ Bluegrass } & \multicolumn{4}{|c|}{ Needlegrass } \\
\hline & & DF & MS & $\mathbf{F}$ & SE & DF & MS & $\mathrm{F}$ & SE \\
\hline Cover & $\begin{array}{l}\text { between } \\
\text { within } \\
\text { total }\end{array}$ & $\begin{array}{r}2 \\
26 \\
28\end{array}$ & $\begin{array}{r}3178 \\
100 \\
320\end{array}$ & $31 *$ & $\begin{array}{l}1.80 \\
3.32\end{array}$ & $\begin{array}{r}1 \\
26 \\
27\end{array}$ & $\begin{array}{r}4094 \\
78 \\
226\end{array}$ & $52 *$ & $\begin{array}{l}1.66 \\
2.84\end{array}$ \\
\hline $\begin{array}{l}\text { Herbage yield } \\
\text { (dry) }\end{array}$ & $\begin{array}{l}\text { between } \\
\text { within } \\
\text { total }\end{array}$ & $\begin{array}{r}2 \\
26 \\
28\end{array}$ & $\begin{array}{r}697 \\
24 \\
71\end{array}$ & $29 *$ & $\begin{array}{r}.90 \\
1.57\end{array}$ & $\begin{array}{r}1 \\
26 \\
27\end{array}$ & $\begin{array}{r}379 \\
12 \\
27\end{array}$ & $\begin{array}{l}32 \\
.98\end{array}$ & .67 \\
\hline $\begin{array}{l}\text { Herbage yield } \\
\text { (wet) }\end{array}$ & $\begin{array}{l}\text { between } \\
\text { within } \\
\text { total }\end{array}$ & $\begin{array}{r}2 \\
26 \\
28\end{array}$ & $\begin{array}{r}2116 \\
69 \\
215\end{array}$ & $30^{*}$ & $\begin{array}{l}1.54 \\
2.72\end{array}$ & $\begin{array}{r}1 \\
26 \\
27\end{array}$ & $\begin{array}{r}510 \\
27 \\
45\end{array}$ & $19 *$ & $\begin{array}{r}.98 \\
1.27\end{array}$ \\
\hline
\end{tabular}

ISignificant at .01 level.

Table 2. Comparison of the simple random and random microsite data sets for the bluegrass and needlegrass communities.

\begin{tabular}{|c|c|c|c|c|c|}
\hline \multirow[b]{2}{*}{ Attribute } & \multirow[b]{2}{*}{ Estimate } & \multicolumn{2}{|c|}{ Bluegrass } & \multicolumn{2}{|c|}{ Needlegrass } \\
\hline & & $\begin{array}{c}\text { Simple } \\
\text { Random } \\
\text { Sample }\end{array}$ & $\begin{array}{l}\text { Random } \\
\text { Microsite } \\
\text { Sample }\end{array}$ & $\begin{array}{l}\text { Simple } \\
\text { Random } \\
\text { Sample }\end{array}$ & $\begin{array}{c}\text { Random } \\
\text { Microsite } \\
\text { Sample }\end{array}$ \\
\hline Cover & $\begin{array}{c}\text { Sample size } \\
\text { Mean (\%) } \\
\text { Standard Error } \\
\text { CI }(.05)\end{array}$ & $\begin{array}{c}29 \\
38.1 \\
3.32 \\
31.4-44.7\end{array}$ & $\begin{array}{c}14 \\
38.4 \\
2.85 \\
32.144 .6\end{array}$ & $\begin{array}{c}28 \\
26.8 \\
2.84 \\
21.1-32.5\end{array}$ & $\begin{array}{c}11 \\
24.0 \\
1.72 \\
20.1-27.9\end{array}$ \\
\hline $\begin{array}{l}\text { Herbage } \\
\text { yield } \\
\text { (dry) }\end{array}$ & $\begin{array}{c}\text { Sample size } \\
\text { Mean }(\mathrm{g} / .1 \mathrm{~m}) \\
\text { Standard error } \\
\mathrm{Cl}(.05)\end{array}$ & $\begin{array}{c}29 \\
13.7 \\
1.57 \\
10.5-16.8\end{array}$ & $\begin{array}{c}14 \\
14.0 \\
1.48 \\
10.7-17.2\end{array}$ & $\begin{array}{c}28 \\
8.8 \\
.98 \\
6.8-10.7\end{array}$ & $\begin{array}{c}11 \\
7.3 \\
.69 \\
5.7-8.8\end{array}$ \\
\hline $\begin{array}{l}\text { Herbage } \\
\text { yield } \\
\text { (wet) }\end{array}$ & $\begin{array}{c}\text { Sample size } \\
\text { Mean }(\mathrm{g} / .1 \mathrm{~m}) \\
\text { Standard error } \\
\mathrm{Cl}(.05)\end{array}$ & $\begin{array}{c}29 \\
27.6 \\
2.72 \\
22.1-33.0\end{array}$ & $\begin{array}{c}14 \\
29.4 \\
.18 \\
25.4-33.3\end{array}$ & $\begin{array}{c}28 \\
17.9 \\
1.27 \\
15.3-20.4\end{array}$ & $\begin{array}{c}11 \\
15.7 \\
.98 \\
13.6-17.8\end{array}$ \\
\hline
\end{tabular}

and Torrie 1980). Consequently, land managers are often faced with a decision to either revise their objectives, due to the necessity of reducing the number of samples collected, or delay the inventory until adequate funds are available.

Microsite sampling within a plant community is an alternative when sample size requirements exceed budgetary constraints. When properly applied, stratified sampling results in smaller var- iances than simple random sampling designs (Cochran 1977). A sample size savings of 50 and $60 \%$ were observed in the tested communities without sacrificing randomization. However, the area occupied by the microsite must be measured accurately to avoid sources of error in the calculation of weighted means and standard errors.

\section{Literature Cited}

Ahmed, J., C. Bonham, and W. Laycock. 1983. Comparison of techniques for adjusting biomass estimated by double sampling. J. Range Manage. 36:217-221.

Butler, S., and L. McDonald. 1983. Unbiased systematic sampling plans for the line intercept method. J. Range Manage. 36:463-468.

Carande, V., and D. Jameson. 1986. Combination of weight estimates with clipped sample data. J. Range Manage. 39:428-431.

Cochran, W.G. 1977. Sampling techniques. John Wiley, New York.

Cooke, R.U., and J.C. Doornkamp. 1974. Geomorphology in environmental management. Clarendon Press, Oxford.

MeQuisten, R., and K. Gebhardt. 1983. Analytical reliability in the decision making process-the numbers game. J. Range Manage. 36:126-128.

Shute, D., and N. West. 1982. Two basic methodological choices in wildland vegetation inventories; their consequences and implications. $J$. Appl. Ecol. 19:249-262.

Snedecor, G.W., and W.G. Cochran. 1978. Statistical methods, 6th ed. lowa State Univ. Press, Ames.

Steel, R., and J. Torrie. 1980. Principles and procedures of statistics, 2nd ed. McGraw-Hill, New York.

Strauss, D., and D. Neal. 1983. Biases in the step point method on bunchgrass ranges. J. Range Manage. 36:623-626.

Taha, F., H. Fisser, and R. Ries. 1983. A modified 100-point frame for vegetation inventory. J. Range Manage. 36:124-125. 